\title{
Testing models of the measuring performance of mutual fund based on single and dual beta
}

\section{Santi Paramita*}

Faculty of Economics,

University of Jenderal Achmad Yani,

Cimahi, Indonesia

Email: veronika.santi@lecturer.unjani.ac.id

\section{Horas Djulius and Ardi Gunardi}

Faculty of Economics,

University of Pasundan,

Bandung, Indonesia

Email: horasdjulius@unpas.ac.id

Email: ardigunardi@unpas.ac.id

\section{Eka Yulianti}

Faculty of Economics,

University of Jenderal Achmad Yani,

Cimahi, Indonesia

Email: yulianti_eka92@yahoo.com

\begin{abstract}
This study aims to test some models of mutual fund performance measurement with regard to the impact of time-varying beta volatility. Testing of models based on three issues: first, the single beta testing; second, dual beta testing; and third determining which model is the most valid and robust. Tests for each models uses a two-pass regression. Testing of comparison model uses a nested model. The research samples were 30 stock mutual funds in the Indonesian capital market period January 2008-December 2012. The results research showed three finding. The first, the single beta testing indicated that these three models were not valid and were not robust. The second, dual beta testing indicated that Treynor-Mazuy model and Paramita model were valid. The third, test of robustness model showed that Paramita model was the most robust than two other models and proved that the market return variable had explanatory power as a determinant factor of mutual fund returns.
\end{abstract}

Keywords: testing models; single beta; dual beta; time-varying beta volatility.

Reference to this paper should be made as follows: Paramita, V.S., Djulius, H., Gunardi, A. and Yulianti, E. (2018) 'Testing models of the measuring performance of mutual fund based on single and dual beta', Int. J. Economic Policy in Emerging Economies, Vol. 11, Nos. 1/2, pp.26-39. 
Biographical notes: V. Santi Paramita received her $\mathrm{PhD}$ degree in Management Department from University of Padjajaran (UNPAD), Bandung, Indonesia, in 2014. She is currently a Lecturer in the Department of Management, the Faculty of Economic at University of Jenderal Achmad Yani (UNJANI), Cimahi, Indonesia. Her current research interests include mutual fund, performance measurement of the portfolio, varying beta, validity and robustness model. She has published several scientific papers in the field of mutual fund and model of performance measurement of the portfolio.

Horas Djulius is an Assistant Professor of Faculty Economics at the University of Pasundan. He is currently the Head of Economics and Development Study Department's Laboratory. He teaches econometrics, research methodology and managerial economics in both undergraduate and post-graduate programs. His research interest focus on knowledge spillover as has been started from his $\mathrm{PhD}$ dissertation in 2005. Currently, he is continuing such research topic to the intersection between macro and micro perspective on knowledge management. Also, he applied research using econometric as a method of data analysis became a focus of research for him as well.

Ardi Gunardi received his Master in Management Science from University of Padjadjaran, Indonesia. He is a Lecturer of Finance at the University of Pasundan, Indonesia. His research interests include financial markets and banking.

Eka Yulianti is a graduate student in the Department of Management University of Padjadjaran, Bandung. Currently, he is an Assistant Lecturer at the University of Jenderal Achmad Yani, Cimahi.

This paper is a revised and expanded version of a paper entitled 'Testing the models of the measuring performance of mutual fund based on single and dual beta' presented at the SIBR-Thammasat Conference, Bangkok, 4-6 June 2015.

\section{Introduction}

Treynor and Mazuy (1966) model is one of model for measuring mutual fund performance that has the superiority to show the ability of investment managers in the portfolio management. The results of empirical studies showed that this model can correct weaknesses of Jensen's alpha model which based on CAPM. Jensen's alpha model assumes that there is a linear relationship between market risk and portfolio return, but in reality is not always linear (Jensen, 1968; Ippolito, 1989; Elton et al., 1993).

On the other side, the model of Treynor-Mazuy has a weakness because establish the market risk as the only risk factor to determine the portfolio return. Several empirical studies show that there are several risk factors besides market risk factors that determine the stock return or portfolio (Ross, 1976; Chen, 1983; Burmeister and McElroy, 1988; Chen and Jordan, 1993; Priestley, 1996; Paramita, 2006). Based on these results, Paramita (2015) tried to rectify the weaknesses of Treynor-Mazuy model by developing Treynor-Mazuy conditional model by adding some macroeconomic variables as 
systematic risk factors. Paramita (2015) result research with constant beta showed that a biased model and indicated the presence of misspecification model. Model testing with two pass regression, show biased model estimate and did not produced a good specification model. These results indicate that there is a problem of time-varying beta. The beta value fluctuates over time as a result of the dynamic changes in economic conditions (Paramita, 2015; Alexander and Strover, 1980).

However, the further model testing by Paramita (2015) that using dual beta successfully improved the model specification. Model testing with separating between up beta and down beta produced Treynor-Mazuy five factors model that valid and robust. Then, this model called Paramita model. Dual beta testing by separating the beta on condition of bullish market (up-beta) and bearish market (down-beta) resulted the two estimation models that proven to be valid and robust. The test results proved that the beta in the Indonesian capital market fluctuating throughout the study period. Beta was moving very volatile to changes in economic conditions of a country (Tandelilin, 2001; Sudarsono, 2003; Paramita, 2015; Bahri, 2015). This condition was causing the time-varying beta problem (Ewing et al., 2003; Flannery and Protopadakis, 2002). Some of the results of empirical studies showed that beta did not stable over time and can not be used as a predictor of stock return or portfolios (Brooks et al., 1988; Ferson et al., 1987; Pettengill et al., 1995, 2002).

Time-varying beta volatility indicates beta did not constant over some period, so that the unstable beta did not can used as a predictor of mutual fund returns. The issue of time-varying beta becomes very fundamental especially during behavioural testing and estimation of beta. Testing the validity of the Treynor-Mazuy conditional model at time-series regression with unstable beta has produced spurious regression (Ferson et al., 2003). Based on some previous empirical studies, has proven that the behaviour of the beta was not stable, not stationary and tends to be time-varying (Fabozzi and Francis, 1977).

Therefore, model testing with considering the condition of time-varying beta volatility was expected to improve the accuracy of the beta. So that beta was relevant as a determinant factor of the expected return (Berglund and Knif, 1999; Bollerslev et al., 1988). Thus, the primary issue of this study is to examine how the impact of time-varying beta volatility on model of mutual fund performance measurement.

This study will analyse the impact of time-varying beta volatility on the model of Jensen's alpha, Treynor-Mazuy and Paramita. The process of model testing will be through three steps. The first steps is establishment Jensen's alpha model, the Treynor-Mazuy model and Paramita model by using two pass regression. The second step is testing the validity and robustness by using nested model. The third step is testing of each model based on the up beta and down beta (dual beta). Furthermore, based on the results of these tests will be conducted the analysis of the impact of time-varying beta volatility for that three models.

In this research, testing of each model was conducted by using two pass regression. Testing of model was done through two steps of regression. In the first regression, testing of model was used time series data to estimate beta. In the second regression, regression conducted between return portfolio with betas that were produced from the first regression (Brown and Weinstein, 1983; Pettengil et al., 1995).

Testing the validity and robustness of the model used a nested model approach. This approach was chosen because these three models define market risk factors as determinants of mutual fund return. Thus, Jensen's alpha model be nested at 
Treynor-Mazuy model. While Treynor-Mazuy model be nested at Paramita model (Gujarati and Porter, 2009; Thomas, 2001).

The next test was a model testing with dual beta to resolve the problem of time-varying beta volatility. The test was conducted by separating the up-beta that indicates a bullish market conditions and down beta which indicates a bearish market in the second pass regression. The dual beta testing produced models that meet the criteria of a good model, namely best, linear, unbias and estimate (BLUE) (Kim and Zumwalt, 1979; Fabozzi and Francis, 1979; Bhardwaj and Books, 1993). Therefore, model testing of mutual fund performance measurement that consideration the time-varying beta volatility will increase the accuracy of the beta. Therefore, the testing produced beta that more relevant as a determinant of the level of expected return (Berglund and Knif, 1999; Bollerslev et al., 1988).

\section{Literature review}

\subsection{Jensen alpha model}

Jensen alpha model developed by Jensen (1968) is a model that shows the difference between the actual rate of return obtained by the portfolio and the expected return if the portfolio is located in the capital market line, with the following equation:

$$
\alpha_{p}=R_{p}-\left[R_{f}+\left(R_{m}-R_{f}\right) \beta_{p}\right]
$$

where

$\alpha_{p}$ measurement of Jensen alpha mutual fund performance

$\beta_{p}$ beta of portfolio

$R_{p} \quad$ average of portfolio return during the observation period

$R_{f} \quad$ average of risk-free return during the observation period

$R_{m t}$ market return on the $t$ period.

The results of Jensen (1968) research found that on average the investment managers could not predict the stock price, so that their portfolio could not outperform the market. While the research result of Grinblatt and Titman (1989) concluded that the superior performance was found on mutual funds that experiencing growth and mutual funds with the smallest net asset value. On the other side, research of Ippolito (1989) concluded that alpha is significantly greater than zero but not enough to cover the average cost of mutual fund.

One disadvantage of this method is the inability of the model in explaining the performance of investment managers as portfolio managers of mutual fund. The performance measurement has not been able to assess how well the investment manager ability to choose the right time to make a purchase or sale of shares of a mutual fund portfolio (market timing ability). 


\subsection{Treynor-Mazuy model}

Treynor and Mazuy (1966) present a model of mutual fund performance measurement by considering the ability of investment manager. The ability of investment managers is measured from their ability on the selection of the right assets as well as their ability to buy and sell assets at the right time. Therefore, the performance of mutual funds is not only influenced by risk factors but also influenced by the ability of investment managers as a manager of assets in mutual fund

This model is a development of CAPM, by adding a quadratic term in the regression equation to accommodate nonlinear factors affecting the expected returns. Parameter of in quadratic term is used to test the market timing. There for, intercept of in this model indicates the ability of stock selectivity while parameter $\beta$ indicates the sensitivity of the portfolio returns on market portfolio return. Treynor-Mazuy model equations:

$$
R_{i t}-R_{f t}=\alpha_{i}+\beta_{i}\left(R_{m t}-R_{f t}\right)+\gamma_{p}\left(R_{m t}-R_{f t}\right)^{2}+e_{i t}
$$

where

$R_{i t}$ return of fund $i$ on $\mathrm{t}$ period

$R_{f t}$ risk-free investment returns

$R_{m t}$ market index return on $\mathrm{t}$ period

$\alpha_{i} \quad$ measurement of stock selection

$\beta_{i} \quad$ unconditional beta

$\gamma_{i} \quad$ market timing coefficient.

While market timing ability is the ability of investment managers to make adjustments toward asset portfolio as anticipate changes or movements of the market price. Therefore, if $\beta_{i}$ positive and significant indicate that the investment manager has market timing ability (Merton, 1981). Treynor and Mazuy (1966) find that the CAPM model has a weakness, because the scatter diagram shows that there is nonlinear relationship between the market risk and the portfolio return. This especially happen in high market volatility condition as a result of bull and bear market which resulted a relationship between market risk and return of portfolio market becomes nonlinear.

Investment managers who have market timing ability will change its portfolio component with beta that has a high value $(\beta>1)$ when the market is rising $\left(R_{m}>R_{f}\right)$. Otherwise when the market is decreasing $\left(R_{m}<R_{f}\right)$, the investment manager will change his portfolio component with beta that has low value $(\beta<1)$. Therefore, the market timing strategy is conducted by buying shares on bullish market conditions and selling stocks when the market is bearish (Jagannathan and Korajczyk, 1986; Graham and Harvey, 1996; Rao, 2000; Gregoriou, 2003). Some of the research supports the use of Treynor-Mazuy model. Treynor-Mazuy model able to demonstrate the ability of investment managers in selecting the right asset (stock selection) which is reflected of the $\alpha$-value. The ability to buy and sell assets at the right time (market timing) which is reflected of the $\gamma_{i}$ value (Chang and Lawellen, 1984; Admati et al., 1985; Kok et al., 2004; Nathani et al., 2011). 


\subsection{Bull and bear market}

Bull market indicates that the active market conditions because there is a rise in stock prices accompanied by the increase in trading volume. While the bear market shows that market conditions flagging because there is a decrease in prices followed by a decrease in trading volumes. Bull and bear market conditions reflecting the presence of fluctuations in stock prices. Some studies often ignore the presence of bull and bear market conditions on the capital markets, so that resulting in the bias estimated value.

Research on the stability of the alpha and beta in bull and bear market conditions, have performed by Fabozzi and Francis (1977). Research results show the value of alpha and beta are not different in bull and bear market conditions. However, in subsequent research, Fabozzi and Francis (1979) prove there are differences beta in mutual funds in bull and bear market conditions.

Pettengill et al. (1995) concluded that in order to estimate the beta needs to establish a model that accommodates differences between beta up and beta down (dual beta) so as not to potentially produce bias beta. Beta up is beta at the time of bullish market, as indicated at the time $R_{m}-R_{f}>0$. While the beta down is beta at the time of bearish market that indicated at the time $R_{m}-R_{f}<0$. It is given that research with constant beta (single beta) can lead to the condition of each other off-set between the beta up and down, so beta potentially produce beta insignificant with a slope that tends to be flat.

Results of subsequent research conducted by Hodoshima et al. (2000) and Sudarsono (2010) shows that there are differences value of the beta at the time beta up and beta down. On the beta up condition will be formed positive beta, whereas on the beta down condition will form a negative beta.

\subsection{Time-varying beta volatility}

Time-varying beta volatility is a condition that shows the fluctuation of the value of beta along with the change in time as a result of the dynamic changes in economic conditions. Beta is not stable over time, so the beta can not used as a predictor of stock return (Brooks et al., 1988; Ferson et al., 1987; Pettengil et al., 1995, 2002).

In the concept of time-varying beta volatility, the variance of stock return can be linked to the level of the arrival of new information. The new information can drive investors to revise their assessment of the intrinsic value of a stock that can cause stock prices fluctuate. Some researchers revealed that the volatility of stock return increases along with arrival from new information, both of good information (good news) and bad information (bad news) (Campbell and Hentschel, 1992). However, the arrival of new information into the market is random or time-varying. Consequently, time-varying beta volatility will cause market risk premium becomes unstable or are time-varying.

\section{Methodology}

\subsection{Research design}

The method used in this research is explanatory survey method or explanatory research. Data sourced on secondary data obtained from various publications issued by financial 
institutions such as Indonesian Central Bank and Indonesia Stock Exchange. This study will conduct behavioural observation of stock mutual fund within five years with monthly data.

Samples were designated as an object of research is the product of stock mutual fund issued by various securities companies and listed on the Jakarta Stock Exchange which has been effective since January 2008 and active until December 2012. Based on purposive sampling criteria, the samples are 30 of stock mutual funds.

Testing data consists of stationary testing data and testing classical assumptions. Tests using two pass regression models consisting of a first pass regression based on data times series and the second pass based on panel data regression. Testing the model is based on the condition of the beta up and down beta (dual beta). Tests carried out on the second pass with a separate regression between beta up and beta down. A selection of the best model based on the results of testing the validity and robustness of the model using the nested models.

\section{Result and discussion}

\subsection{Identification result about time-varying beta volatility}

First pass regression testing based on time series data produced beta estimation that showed there was beta high volatility over time. These were indicated that there is time-varying beta volatility that was seen in Figure 1.

Figure 1 Time-varying beta volatility (see online version for colours)

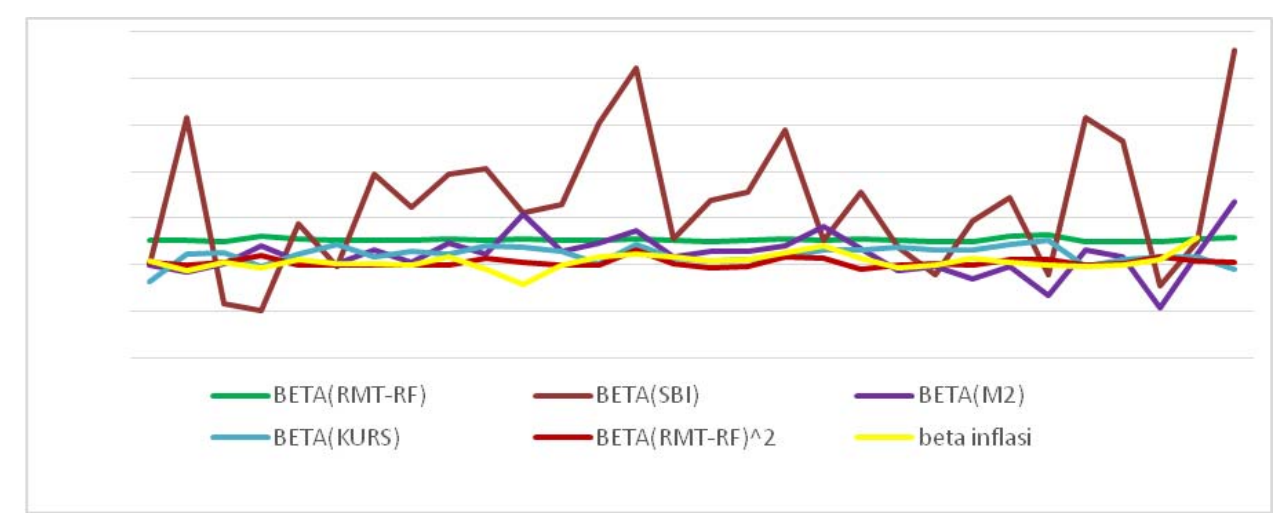

\subsection{Test result of models}

The testing of each model is based on two pass regression. Testing of first pass regression produced betas estimation of time series regression. Betas estimation betas are then regressed with the portfolio return on the second pass regression based on cross-section data. The test results of three models can be seen in Table 1 until Table 3 as follows: 
Table 1 Test result Jensen's alpha model with single and dual beta on the second pass regression (panel A)

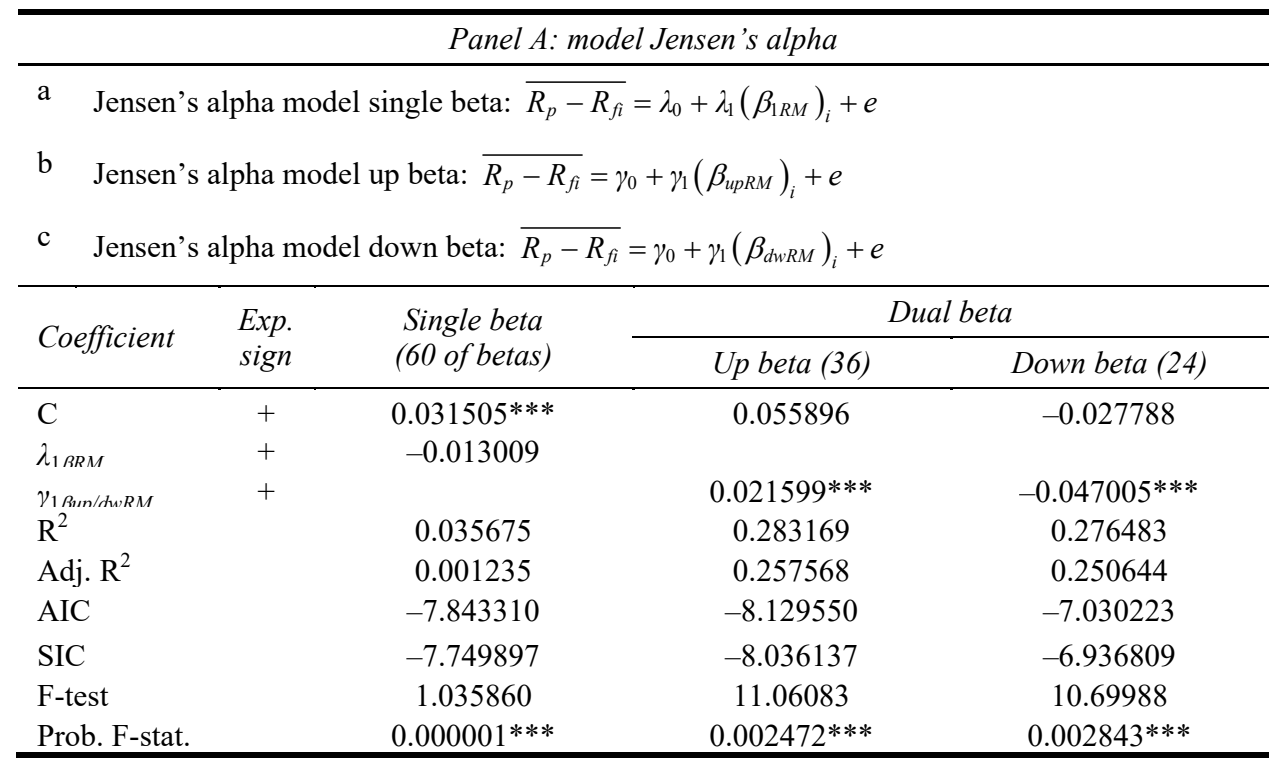

Notes: ***Significant at level of $1 \% ; * *$ significant at level of $5 \%$; *significant at level of $10 \%$; $\lambda_{1 \beta R M} ; \gamma_{1 \beta u p / d w R M}$ is risk free factor; $\lambda_{2 \beta I N F} ; \gamma_{1 I N F}$ is inflation risk factor;

$\lambda_{3 \beta S B I} ; \gamma_{3 \beta u p / d w S B I}$ is interest rate risk factor; $\lambda_{4 \beta J U B} ; \gamma_{4 \beta u p / d w M 2}$ is money supply risk factor; $\lambda_{5 \beta K U R S} ; \gamma_{5 \beta \text { Bup } / d w K U R S}$ is exchange rate risk factor;

$\lambda_{6 \beta M T} ; \gamma_{6 \beta u p / d w M T}$ is market timing.

Table 2 Test result Treynor-Mazuy model with single and dual beta on the second pass regression (panel B)

\begin{tabular}{|c|c|c|c|c|c|}
\hline \multicolumn{6}{|c|}{ Panel B: model Treynor-Mazuy } \\
\hline $\mathrm{a}$ & \multicolumn{5}{|c|}{ Treynor-Mazuy model single beta: $\overline{R_{p}-R_{f i}}=\lambda_{0}+\lambda_{1}\left(\beta_{1}\right)_{i}+\lambda_{6}\left(\beta_{6}\right)_{i} e$} \\
\hline $\mathrm{b}$ & \multicolumn{5}{|c|}{ Treynor-Mazuy model up beta: $\overline{R_{p}-R_{f i}}=\gamma_{0}+\gamma_{1}\left(\beta_{1 u p}\right)_{i}+\gamma_{6}\left(\beta_{6 u p}\right)_{i}+e$} \\
\hline $\mathrm{c}$ & \multicolumn{5}{|c|}{ Treynor-Mazuy model down beta: $\overline{R_{p}-R_{f i}}=\gamma_{0}+\gamma_{1}\left(\beta_{1 u p}\right)_{i}+\gamma_{6}\left(\beta_{6 u p}\right)_{i}+e$} \\
\hline \multirow{2}{*}{\multicolumn{2}{|c|}{ Coefficient }} & \multirow{2}{*}{$\begin{array}{l}\text { Exp. } \\
\text { sign }\end{array}$} & \multirow{2}{*}{$\begin{array}{l}\text { Single beta } \\
\text { ( } 60 \text { of betas) }\end{array}$} & \multicolumn{2}{|c|}{ Dual beta } \\
\hline & & & & Up beta (36) & Down beta (24) \\
\hline C & & + & 0.032156 & 0.052752 & -0.009533 \\
\hline \multicolumn{2}{|c|}{$\lambda_{1 \beta R M}$} & + & -0.013927 & & \\
\hline \multicolumn{2}{|c|}{$\gamma_{6 \beta M T}$} & + & 0.003114 & & \\
\hline \multicolumn{2}{|c|}{$\gamma_{1 B u p / d w R M}$} & $+/-$ & & $0.024740 * *$ & $-0.062678 * * *$ \\
\hline \multicolumn{2}{|c|}{$\gamma_{6 \beta u p M T}$} & & & $0.005390 * * *$ & $0.013576^{* *}$ \\
\hline
\end{tabular}

Notes: ***Significant at level of $1 \%$; **significant at level of $5 \%$; *significant at level of $10 \% ; \lambda_{1 \beta R M} ; \gamma_{1 \beta u p / d w R M}$ is risk free factor; $\lambda_{2 \beta I N F} ; \gamma_{1 I N F}$ is inflation risk factor; $\lambda_{3 \beta S B I} ; \gamma_{3 \beta u p / d w S B I}$ is interest rate risk factor; $\lambda_{4 \beta J U B} ; \gamma_{4 \beta u p / d w M 2}$ is money supply risk factor; $\lambda_{5 \beta K U R S} ; \gamma_{5 \beta u p / d w K U R S}$ is exchange rate risk factor; $\lambda_{6 \beta M T} ; \gamma_{6 \beta u p / d w M T}$ is market timing. 
Table 2 Test result Treynor-Mazuy model with single and dual beta on the second pass regression (panel B) (continued)

\begin{tabular}{|c|c|c|c|c|c|}
\hline \multicolumn{6}{|c|}{ Panel B: model Treynor-Mazuy } \\
\hline $\mathrm{a}$ & \multicolumn{5}{|c|}{ Treynor-Mazuy model single beta: $\overline{R_{p}-R_{f i}}=\lambda_{0}+\lambda_{1}\left(\beta_{1}\right)_{i}+\lambda_{6}\left(\beta_{6}\right)_{i} e$} \\
\hline b & \multicolumn{5}{|c|}{ Treynor-Mazuy model up beta: $\overline{R_{p}-R_{f i}}=\gamma_{0}+\gamma_{1}\left(\beta_{1 u p}\right)_{i}+\gamma_{6}\left(\beta_{6 u p}\right)_{i}+e$} \\
\hline $\mathrm{c}$ & \multicolumn{5}{|c|}{ Treynor-Mazuy model down beta: $\overline{R_{p}-R_{f i}}=\gamma_{0}+\gamma_{1}\left(\beta_{1 u p}\right)_{i}+\gamma_{6}\left(\beta_{6 u p}\right)_{i}+e$} \\
\hline \multirow{2}{*}{\multicolumn{2}{|c|}{ Coefficient }} & \multirow{2}{*}{$\begin{array}{l}\text { Exp. } \\
\text { sign }\end{array}$} & \multirow{2}{*}{$\begin{array}{l}\text { Single beta } \\
\text { (60 of betas) }\end{array}$} & \multicolumn{2}{|c|}{ Dual beta } \\
\hline & & & & Up beta (36) & Down beta (24) \\
\hline \multicolumn{3}{|c|}{$\mathrm{R}^{2}$} & 0.041783 & 0.287866 & 0.521721 \\
\hline \multicolumn{3}{|c|}{ Adj. $R^{2}$} & -0.029196 & 0.235116 & 0.486293 \\
\hline \multicolumn{3}{|c|}{$\mathrm{AIC}$} & -7.782998 & -8.069458 & -7.377485 \\
\hline \multicolumn{3}{|c|}{ SIC } & -7.642878 & -7.929338 & -7.237365 \\
\hline \multicolumn{3}{|c|}{ F-test } & 0.588671 & 5.457115 & 14.72620 \\
\hline \multicolumn{3}{|c|}{ Prob. F-stat. } & 0.562031 & $0.010223 * *$ & $0.000047 * * *$ \\
\hline
\end{tabular}

Notes: ***Significant at level of $1 \% ; * *$ significant at level of $5 \%$; *significant at level of

$10 \% ; \lambda_{1 \beta R M} ; \gamma_{1 \beta u p / d w R M}$ is risk free factor; $\lambda_{2 \beta I N F} ; \gamma_{1 I N F}$ is inflation risk factor;

$\lambda_{3 \beta S B I} ; \gamma_{3 \beta u p / d w S B I}$ is interest rate risk factor; $\lambda_{4 \beta J U B} ; \gamma_{4 \beta u p / d w M 2}$ is money supply risk factor; $\lambda_{5 \beta K U R S} ; \gamma_{5 \beta u p / d w K U R S}$ is exchange rate risk factor;

$\lambda_{6 \beta M T} ; \gamma_{6 \beta u p / d w M T}$ is market timing.

Table 3 Test result Paramita model with single and dual beta on the second pass regression (panel C)

\begin{tabular}{|c|c|c|c|c|}
\hline \multicolumn{5}{|c|}{ Panel B: Paramita model } \\
\hline \multicolumn{5}{|c|}{ a Paramita model single beta: $\begin{aligned} \overline{R_{p}-R_{f i}} & =\lambda_{0}+\lambda_{1}\left(\beta_{R M}\right)_{i}+\lambda_{2}\left(\beta_{I N F}\right)_{i}+\lambda_{3}\left(\beta_{S B I}\right)_{i} \\
& +\lambda_{4}\left(\beta_{M 2}\right)_{i}+\lambda_{5}\left(\beta_{K U R S}\right)_{i}+\lambda_{6}\left(\beta_{M T}\right)_{i}+e\end{aligned}$} \\
\hline b & \multicolumn{4}{|c|}{ Paramita model up beta: $\begin{aligned} \overline{R_{p}-R_{f i}} & =\gamma_{0}+\gamma_{1}\left(\hat{\beta}_{u p R M}\right)_{i}+\gamma_{2}\left(\hat{\beta}_{u p I N F}\right)_{i}+\gamma_{3}\left(\hat{\beta}_{u p S B I}\right)_{i} \\
& +\gamma_{4}\left(\hat{\beta}_{u p M 2}\right)_{i}+\gamma_{5}\left(\hat{\beta}_{u p K U R S}\right)_{i}+\gamma_{6}\left(\hat{\beta}_{u p M T}\right)_{i}+e\end{aligned}$} \\
\hline $\mathrm{c}$ & \multicolumn{4}{|c|}{ Paramita model down beta: $\begin{aligned} \overline{R_{p}-R_{f i}} & =\gamma_{0}+\gamma_{1}\left(\hat{\beta}_{d w R M}\right)_{i}+\gamma_{2}\left(\hat{\beta}_{d w I N F}\right)_{i}+\gamma_{3}\left(\hat{\beta}_{d w S B I}\right)_{i} \\
& +\gamma_{4}\left(\hat{\beta}_{d w M 2}\right)_{i}+\gamma_{5}\left(\hat{\beta}_{d w K U R}\right)_{i}+\gamma_{6}\left(\hat{\beta}_{d w M T}\right)_{i}+e\end{aligned}$} \\
\hline \multirow{2}{*}{\multicolumn{2}{|c|}{ Coefficient }} & \multirow{2}{*}{$\begin{array}{l}\text { Exp. } \\
\text { sign }\end{array}$} & \multicolumn{2}{|c|}{ Dual beta } \\
\hline & & & Up beta (36) & Down beta (24) \\
\hline \multicolumn{2}{|c|}{$\mathrm{C}$} & 0.010086 & $0.043384 * * *$ & -0.018715 \\
\hline \multicolumn{2}{|c|}{$\lambda_{1 \beta R M}$} & 0.005671 & & \\
\hline \multicolumn{2}{|c|}{$\lambda_{2 \beta \mathrm{INF}}$} & 0.150572 & & \\
\hline \multicolumn{2}{|c|}{$\lambda_{3 \beta S B I}$} & $0.001219 * * *$ & & \\
\hline
\end{tabular}

Notes: ***Significant at level of $1 \% ; * *$ significant at level of $5 \%$; *significant at level of $10 \% ; \lambda_{1 \beta R M} ; \gamma_{1 \beta u p / d w R M}$ is risk free factor; $\lambda_{2 \beta I N F} ; \gamma_{1 I N F}$ is inflation risk factor;

$\lambda_{3 \beta S B I} ; \gamma_{3 \beta u p / d w S B I}$ is interest rate risk factor; $\lambda_{4 \beta J U B} ; \gamma_{4 \beta u p / d w M 2}$ is money supply risk factor; $\lambda_{5 \beta K U R S} ; \gamma_{5 \beta u p / d w K U R S}$ is exchange rate risk factor;

$\lambda_{6 \beta M T} ; \gamma_{6 \beta u p / d w M T}$ is market timing. 
Table 3 Test result Paramita model with single and dual beta on the second pass regression (panel C) (continued)

\begin{tabular}{|c|c|c|c|c|c|}
\hline \multicolumn{6}{|c|}{ Panel B: Paramita model } \\
\hline \multicolumn{6}{|c|}{ a Paramita model single beta: $\begin{aligned} \overline{R_{p}-R_{f i}} & =\lambda_{0}+\lambda_{1}\left(\beta_{R M}\right)_{i}+\lambda_{2}\left(\beta_{I N F}\right)_{i}+\lambda_{3}\left(\beta_{S B I}\right)_{i} \\
& +\lambda_{4}\left(\beta_{M 2}\right)_{i}+\lambda_{5}\left(\beta_{K U R S}\right)_{i}+\lambda_{6}\left(\beta_{M T}\right)_{i}+e\end{aligned}$} \\
\hline \multicolumn{6}{|c|}{ b Paramita model up beta: $\begin{aligned} \overline{R_{p}-R_{f i}} & =\gamma_{0}+\gamma_{1}\left(\hat{\beta}_{u p R M}\right)_{i}+\gamma_{2}\left(\hat{\beta}_{u p I N F}\right)_{i}+\gamma_{3}\left(\hat{\beta}_{u p S B I}\right)_{i} \\
& +\gamma_{4}\left(\hat{\beta}_{u p M 2}\right)_{i}+\gamma_{5}\left(\hat{\beta}_{u p K U R S}\right)_{i}+\gamma_{6}\left(\hat{\beta}_{u p M T}\right)_{i}+e\end{aligned}$} \\
\hline c & \multicolumn{5}{|c|}{ Paramita model down beta: $\begin{array}{r}\overline{R_{p}-R_{f i}} \\
=\gamma_{0}+\gamma_{1}\left(\hat{\beta}_{d w R M}\right)_{i}+\gamma_{2}\left(\hat{\beta}_{d w I N F}\right)_{i}+\gamma_{3}\left(\hat{\beta}_{d w S B I}\right)_{i} \\
\\
+\gamma_{4}\left(\hat{\beta}_{d w M 2}\right)_{i}+\gamma_{5}\left(\hat{\beta}_{d w K U R}\right)_{i}+\gamma_{6}\left(\hat{\beta}_{d w M T}\right)_{i}+e\end{array}$} \\
\hline \multirow{2}{*}{\multicolumn{2}{|c|}{ Coefficient }} & \multirow{2}{*}{$\begin{array}{l}\text { Exp. } \\
\text { sign }\end{array}$} & \multirow{2}{*}{$\begin{array}{l}\text { Single beta } \\
\text { (60 of betas) }\end{array}$} & \multicolumn{2}{|c|}{ Dual beta } \\
\hline & & & & Up beta (36) & Down beta (24) \\
\hline \multicolumn{2}{|c|}{$\lambda_{4 \beta M 2}$} & + & $-359,988.1 * * *$ & & \\
\hline \multicolumn{2}{|c|}{$\lambda_{5 \beta K U R S}$} & + & -158.2418 & & \\
\hline \multicolumn{2}{|c|}{$\lambda_{6 \beta M T}$} & $+/-$ & -0.000949 & & \\
\hline \multicolumn{2}{|c|}{$\gamma_{1 \beta u p / d w R M}$} & + & & $0.032920^{* * *}$ & $-0.057089 * * *$ \\
\hline \multicolumn{2}{|c|}{$\gamma_{2 \beta \mathrm{up} / \mathrm{dwINF}}$} & - & & 0.002147 & 0.377874 \\
\hline \multicolumn{2}{|c|}{$\gamma_{3 \beta u p / d w S B I}$} & - & & $0.000684 * * *$ & $0.000673 *$ \\
\hline \multicolumn{2}{|c|}{$\gamma_{4 \beta u p / d w J U B}$} & $-1+$ & & $-286,374.1 * * *$ & $-272,555.6^{* * *}$ \\
\hline \multicolumn{2}{|c|}{$\gamma_{5 \beta u p / d w K U R S}$} & + & & $-363.3559 * *$ & $394.0255^{* * *}$ \\
\hline \multicolumn{3}{|c|}{$\gamma_{6 \beta и р M T}$} & & $0.006221 * * *$ & $0.010147^{*}$ \\
\hline \multicolumn{3}{|c|}{$\mathrm{R}^{2}$} & 0.608796 & 0.833713 & 0.648123 \\
\hline \multicolumn{3}{|c|}{ Adj. $R^{2}$} & 0.506743 & 0.790334 & 0.556329 \\
\hline \multicolumn{3}{|c|}{ AIC } & -8.4121 & -8.0122 & -7.0302 \\
\hline \multicolumn{3}{|c|}{ SIC } & -8.3075 & $-7,9188$ & -6.9368 \\
\hline \multicolumn{3}{|c|}{ F-test } & $5.965475^{*}$ & $19.21919 * * *$ & $7.060623 * * *$ \\
\hline \multicolumn{3}{|c|}{ Prob. F-stat } & $0.000712 * * *$ & $0.000000 * * *$ & $0.000235 * * *$ \\
\hline
\end{tabular}

Notes: ***Significant at level of $1 \% ; * *$ significant at level of $5 \%$; *ignificant at level of $10 \% ; \lambda_{1 \beta \mathrm{RM}} ; \gamma_{1 \beta u p / d w R M}$ is risk free factor; $\lambda_{2 \beta I N F} ; \gamma_{1 I N F}$ is inflation risk factor;

$\lambda_{3 \beta S B I} ; \gamma_{3 \beta u p / d w S B I}$ is interest rate risk factor; $\lambda_{4 \beta J U B} ; \gamma_{4 \beta u p / d w M 2}$ is money supply risk factor; $\lambda_{5 \beta K U R S} ; \gamma_{5 \beta u p / d w K U R S}$ is exchange rate risk factor;

$\lambda_{6 \beta M T} ; \gamma_{6 \beta u p / d w M T}$ is market timing.

\subsection{Validity and robustness test result of the models with single beta}

The validity test result of Jensen's alpha model with a single beta (panel A) with t-test and F-test produce no significant value. This test indicates that Jensen's alpha model is invalid model and inconsistent with the theory.

The validity test result of Treynor-Mazuy model with single beta (panel B) shows that the results of t-test produces $\lambda_{1 \beta R M}$ value (market risk factors) and $\lambda_{6 \beta M T}$ value (market timing factors) do not significant for. This result indicates that the market risk factor and 
factor market timing proved unable to explain the variations in returns of stock mutual fund. The negative value of $\lambda_{1 \beta 1}$ indicates that the effect of market risk toward stock mutual fund returns does not support the theory. While the value of $\lambda_{6 \beta M T}$ which positive indicates that stock mutual fund has a good performance of market timing. The F-test results showed, Treynor-Mazuy model not significant. Therefore, the results of t-test and F-test prove that Treynor-Mazuy model is invalid model.

The validity test result of Paramita model with a single beta (panel C) shows the results of $t$-test that there were two variables was significant, namely $\lambda_{3 \beta S B I}$ (SBI interest rate risk factors) and $\lambda_{4 \beta J U B}$ (risk factor in the money supply). While four other variables are not significant. The F-test results showed Paramita model is significant.

The robustness test model shows that Paramita model with single beta meet the criteria for goodness of fit. The result test shows that Paramita model has highest value of $\mathrm{R}^{2}$ and Adj. $\mathrm{R}^{2}$ at $60.87 \%$ and $50.67 \%$ is compared with the other models. While based on the criteria of Akaike and Schwartz, Paramita model meet the criteria of the best model because it has the lowest value of AIC and SIC at -8.412176 and -8.412176 were compared with the other models.

\subsection{Validity and robustness test result of the models with dual beta}

The validity test result of Jensen's alpha model with dual beta shows value of $\lambda_{1 \beta 1}$ that significant positive for up beta and significant negative for down beta. This indicates that the market risk factors proved to be able to explain variations in the return of stock mutual fund. The F-test results showed that Jensen's alpha model was significant. Therefore, the results of t-test and F-test proved that Jensen's alpha model based on up and down beta test are valid and consistent to support the theory.

The validity test result of Treynor-Mazuy model with dual beta shows value of $\lambda_{1 \beta 1}$ (market risk factors) significantly positive for up beta and significant negative for down beta.

Similarly value of $\lambda_{6 M T}$ (market timing factors) shows significantly positive for up and down beta. This indicates the market risk factor and market timing factor proved to be able to explain the variations in returns of stock mutual fund. The F-test result showed Treynor-Mazuy model significant on the up and down beta. Therefore, result of t-test and F-test prove that the model of Treynor-Mazuy is valid and consistent to support the theory.

The validity test result of Paramita model with dual beta shows significant value for all independent variables, except the inflation variable. The F-test result shows that Paramita model is significant on up and down beta. Therefore, the results of t-test and F-test prove that the Paramita model is valid and consistent to support the theory.

The robustness test model test shows that Paramita model is meet the criteria of the goodness of fit on the condition up and down beta. There is the highest value of $\mathrm{R}^{2}$ and Adj. $\mathrm{R}^{2}$. The value of $\mathrm{R}^{2}$ is 0.833713 for up beta and 0.648123 for down beta. While value of Adj. $\mathrm{R}^{2}$ is 0.790334 for up beta and 0.556329 for down beta. While based on the criteria of Akaike and Schwartz, Paramita model meet the criteria of the best model because it has the lowest AIC and SIC. The value of AIC is -8.0122 for up beta and -7.0302 for down beta. Then, the value of SIC for -7.9188 of up beta and -6.9368 of down beta. 
The nested test result of three models shows that market risk factors consistently produce positive and significant coefficient. This result indicates the market risk factor is the main factor that has explanatory power in explaining the portfolio return. On the other side, the value of $\mathrm{R}^{2}$ and Adj. $\mathrm{R}^{2}$ on Paramita model with dual beta test showed the highest value. This also indicates the Paramita model or Treynor-Mazuy conditional model is the best model than the others models. Increase in the value of $\mathrm{R}^{2}$ and Adj. $\mathrm{R}^{2}$ at Paramita model, shows that the addition of some economic variables in the Treynor-Mazuy model is able to produce a good model.

\section{Conclusions}

The results of single beta testing on Jensen's Alpha model, Treynor-Mazuy model and Paramita model produce invalid models and inconsistent to support the theory. However, dual beta testing with separating between up and down beta is able to improve the validity and specifications of the models. The nested model test shows that the Paramita model is the best model compared with Jensen's alpha model and Treynor-Mazuy model. The test results also showed that the market risk factor is the main factor which has explanatory power in explaining portfolio returns.

\section{References}

Admati, A.R., Bhattacharya, S., Ross, S.A. and Pfleiderer, P. (1985) 'On timing and selectivity', Journal of Finance, Vol. 41, No. 3, pp.715-730.

Alexander, G.J. and Strover, R.D. (1980) 'Consistency of mutual fund performance during varying market conditions', Journal of Economics and Business, Spring, Vol. 32, No. 3, pp.219-225.

Bahri (2015) 'The volatility of industrial stock returns and an empirical test of arbitrage pricing theory', Review of Integrative Business and Economics Research, Vol. 4, No. 2, pp.254-277.

Berglund, T. and Knif, J. (1999) 'Accounting for the accuracy of beta estimates in CAPM test on asset with time-varying risk', European Financial Management, Vol. 5, No. 1, pp.29-42.

Bhardwaj, R.K. and Brooks, L.D. (1993) 'Dual betas from bull and bear market: reversal of the size effect', The Journal of Financial Research, Vol. 16, No. 4, pp.183-269.

Bollerslev, T., Engle, R.F. and Wolldridge, J.M. (1988) 'A capital asset pricing model with time-varying covariances', Journal of Political Economy, Vol. 96, No. 1, pp.116-131.

Brooks, R.D., Faff, R.W. and Affif, M. (1988) 'An investigation into the extend of beta instability in the Singapore Stock Market', Pacific-Basin Finance Journal, Vol. 6, Nos. 1-2, pp.87-101.

Brown, S.J. and Weinstein, M.I. (1983) 'A new approach to testing asset pricing models: the bilinear paradigm', The Journal of Finance, Vol. 38, No. 3, pp.711-743.

Burmeister, E. and McElroy, B. (1988) 'Joint estimation of factor sensitivities and risk premia for the arbitrage pricing theory', The Journal of Finance, Vol. 43, No. 3, pp.721-733.

Campbell, J.Y. and Hentschel, L. (1992) 'No new is good news: an asymmetric model of changing volatility in stock return', Journal of Financial Economics, Vol. 31, No. 3, pp.281-318.

Chang, E.C. and Lawellen, W.G. (1984) 'Market timing and mutual fund performance', Journal of Business, Vol. 57, No. 11, pp.73-96.

Chen, N.F. (1983) 'Some empirical tests of the theory of abitrage pricing', Journal of Finance, Vol. 38, No. 5, pp.1393-1414. 
Chen, S.J. and Jordan, B.D. (1993) 'Some empirical tests of the APT: macrovariables versus derived factors', Journal of Banking and Finance, Vol. 17, No. 1, pp.65-90.

Elton, E.J., Gruber, M.J., Das, S. and Hlavka, M. (1993) 'Efficiency with costly information: a reinterpretation of evidence from manager portfolios', Review of Financial Studies, Vol. 6, No. 1, pp.1-23.

Ewing, B.T., Forbes, S.M. and Payne, J.E. (2003) 'The effect of macroeconomic shock on sector-specific return', Applied Economics, Vol. 35, No. 2, pp.201-207.

Fabozzi, F.J. and Francis, J.C. (1977) 'Stability tests for alphas and betas over bull and bear market conditions', Journal of Finance, Vol. 32, No. 4, pp.1093-1099.

Fabozzi, F.J. and Francis, J.C. (1979) 'Mutual fund systematic risk for bull and bear market', Journal of Finance, December, Vol. 34, No. 5, pp.43-50.

Ferson, W.E., Kandel, S. and Stambaugh, R.F. (1987) 'Test of asset pricing with time-varying expected risk premiums and market betas', Journal of Finance, June, Vol. 42, No. 2, pp.201-220.

Ferson, W.E., Sarkissian, S. and Simin, T.T. (2003) 'Spurious regression in financial economics?', The Journal of Finance, August, Vol. 58, No. 4, pp.1393-1414.

Flannery, M.J. and Protopapadakis, A.A. (2002) 'Macroeconomic factors do influence aggregate stock returns', The Review of Financial Studies, Vol. 15, No. 3, pp.751-782.

Graham, J.R. and Harvey, C.R. (1996) 'Market timing ability and volatility implied in investment newsletters' asset allocation', Journal of Finance Economics, Vol. 42, No. 3, pp.397-421.

Gregoriou, G.N. (2003) 'Market timing and selectivity abilities of fund of hedge fund managers using conditional alphas and betas', Derivatives Use, Trading and Regulation, Vol. 8, No. 4, pp.324-344.

Grinblatt, M. and Titman, S. (1989) 'Mutual fund performance: an analysis of quarterly portfolio holdings', Journal of Business, Vol. 62, No. 3, pp.393-416.

Gujarati, D.N. and Porter, D.C. (2009) Basic Econometric, 5th ed., McGraw-Hill Companies Inc., New York.

Hodoshima, J., Gomez, X.G. and Kunimura, M. (2000) 'Cross-sectional regression analysis or return and beta in Japan', Journal of Economics and Business, Vol. 52, pp.515-533.

Ippolito, R.A. (1989) 'Efficiency with costly information: a study of mutual funds', Quarterly Journal of Economics, Vol. 104, No. 1, pp.1-23.

Jagannathan, R. and Korajczyk, R.A. (1986) 'Assessing the market timing performance of managed portfolios', The Journal of Business, Vol. 59, No. 2, pp.217-235.

Jensen, M. (1968) 'The performance of the mutual funds in the period 1954-1964', Journal of Finance, May, Vol. 23, No. 2, pp.384-416.

Kim, M.K. and Zumwalt, J.K. (1979) 'An analysis of risk in bull and bear markets', Journal of Financial and Quantitative Analysis, Vol. 14, No. 5, pp.1015-1025.

Kok, K.L., Goh, K.L. and Wong, Y.C. (2004) 'Selectivity and market timing of Malaysian unit trust', Malaysian Journal of Economic Studies, Vol. 41, Nos. 1/2, pp.71-86.

Merton, R.C. (1981) 'On market timing and investment performance: I: an equilibrium theory of value for market forecast', Journal of Business, July, Vol. 54, pp.363-406.

Nathani, N., Chakraborty, A., Rawat, B. and Holani, U. (2011) 'Timing skills of fund managers: a study of equity mutual fund schemes', Journal of Business Spectrum, June, Vol. 1, No. 1, pp.9-18.

Paramita, V.S. (2006) 'Pengaruh Beberapa Variabel Ekonomi Makro Terhadap Nilai Aktiva Bersih Reksa Dana Per Unit Reksa Dana Saham', Jurnal Portofolio, Vol. 3, No. 2, pp.48-61.

Paramita, V.S. (2015) 'Testing model Treynor-Mazuy conditional model in bull and bear market', Review of Integrative Business and Economics Research, Vol. 4, No. 2, pp.208-219.

Pettengill, G.N., Sundarman, S. and Marthur, I. (1995) 'The conditional relation between beta and returns', Journal of Financial and Quantitative Analysis, Vol. 30, No. 1, pp.101-116. 
Pettengill, G.N., Sundarman, S. and Marthur, I. (2002) 'Payment for risk: constant beta vs. dual-beta models', The Financial Review, Vol. 37, No. 2, pp.123-135.

Priestley, R. (1996) 'The arbitrage pricing theory, macro-economic and financial factors, and expectations generating processes', The Journal of Banking and Finance, Vol. 20, No. 5, pp.869-890.

Rao, S.P.U. (2000) 'Market timing and mutual fund performance', American Business Review, June, Vol. 18, No. 2, pp.75-79.

Ross, A. (1976) 'The abritrage theory of capital asset pricing', Journal of Economic Theory, Vol. 13, No. 3, pp.341-360.

Sudarsono, R. (2003) 'Pengujian Model-Model Ekuilibrium: Perbandingan Model CAPM dengan Model APT di Bursa Efek Jakarta', Jurnal Bisnis dan Manajemen, Vol. 2, No. 1, pp.97-126.

Tandelilin, E. (2001) 'Beta Pada Pasar Bullish dan Bearish: Studi Empiris di Bursa Efek Jakarta', Journal of Indonesian Economy and Business, Vol. 16, No. 13, pp.261-272, Fakultas Ekonomi Universitas Gadjah Mada, Yogyakarta.

Thomas, R.L. (2001) Modern Econometrics: An Introduction, Addison Wesley Longman Limited. England.

Treynor, J. and Mazuy, F. (1966) 'Can mutual funds outguess the market?', Harvard Business, Vol. 44, No. 4, pp.131-136. 